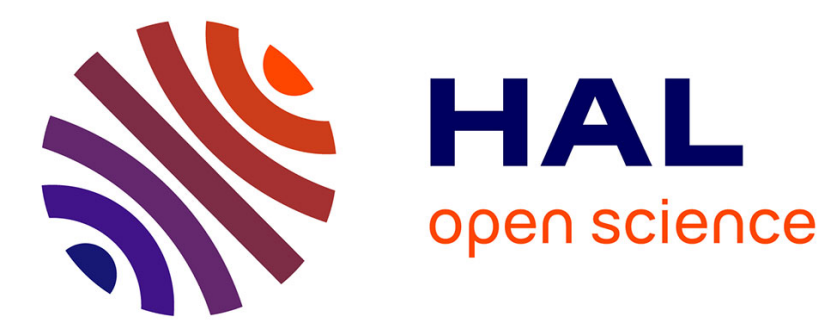

\title{
Counteracting counterfeiting? Bodin, Mariana and Locke on false money as a multidimensional issue
}

\author{
Jérôme Blanc, Ludovic Desmedt
}

\section{To cite this version:}

Jérôme Blanc, Ludovic Desmedt. Counteracting counterfeiting? Bodin, Mariana and Locke on false money as a multidimensional issue. History of Political Economy, 2010, 42 (2), pp.323-360. 10.1215/00182702-2010-005 . halshs-00583586

\section{HAL Id: halshs-00583586 \\ https://shs.hal.science/halshs-00583586}

Submitted on 17 Oct 2015

HAL is a multi-disciplinary open access archive for the deposit and dissemination of scientific research documents, whether they are published or not. The documents may come from teaching and research institutions in France or abroad, or from public or private research centers.
L'archive ouverte pluridisciplinaire HAL, est destinée au dépôt et à la diffusion de documents scientifiques de niveau recherche, publiés ou non, émanant des établissements d'enseignement et de recherche français ou étrangers, des laboratoires publics ou privés.

\section{다)(1) $(5$}

Distributed under a Creative Commons Attribution - NonCommerciall 4.0 International 


\title{
Counteracting counterfeiting? Bodin, Mariana and Locke on false money as a multidimensional issue
}

Jérôme Blanc (LEFI - Laboratoire d'économie de la firme et des institutions) Ludovic Desmedt (LEG - Laboratoire d'économie et de gestion)

Published in :

Desmedt Ludovic, Blanc Jérôme, « Counteracting Counterfeiting? Bodin, Mariana, and Locke on False Money as a Multidimensional Issue », History of Political Economy, 20 juin 2010, vol. 42, n 2, p. 323-360.

\begin{abstract}
Far beyond the problem of the quantity of money, false money appears as the general common issue in monetary debates that occurred in European countries in the 16th and 17th centuries. It first referred to sovereignty, in a time of state-building, as well as to a serious economic problem. Beyond sovereignty and economy, justice and the public faith were endangered by those who devoted themselves to falsify the currency. Yet, the thesis of this paper is that one cannot understand clearly the general topic of false money in the early modern period by reading texts of that time with today's general definition of false money. The variety of falsifications and their links appear especially when carefully reading the monetary discourses of Jean Bodin, Juan de Mariana and John Locke. These authors developed major arguments about the limits of political powers, elements which innerved their visions of currency management. A general claim to counteract counterfeiting (as implemented by individuals) may conceal a claim to suppress any possibility of debasing, and even enhancing, currency (as decided by princes). Making clearer monetary discourses on that topic and establishing a hierarchy between those dimensions help understand why the false money issue was firstly considered a matter of monetary justice by the prince himself. We propose, then, to identify the multiple dimensions of false money: counterfeiting, degradation of coins, debasement and enhancement; while some are the result of individuals, others are princes' decisions. Until the end of the $17^{\text {th }}$ century, monetary instability impeded the development of production on the long run. Stabilizations, through a monetary revolution close to what had been proposed by Bodin, Mariana and Locke, occurred between the end of the $17^{\text {th }}$ and the beginning of the $18^{\text {th }}$ century.
\end{abstract}




\section{Counteracting counterfeiting? Bodin, Mariana and Locke on false money as a multidimensional issue ${ }^{1}$}

\section{Introducing the problem}

In the beginning of the fourteenth century, the Florentine poet Dante Alighieri penned a famous allusion to his contemporary, the French king Philip IV the Fair, in his Divina Commedia:

"There shall be seen the woe that on the Seine

He brings by falsifying of the coin,

Who by the blow of a wild boar shall die" (Dante Alighieri, 1867, canto

XIX, v.118-120) ${ }^{2}$.

Dante suggested that Philip's death following an accident was only justice after the falsifications of his reign (1285-1314). In 1301, he had already been accused of falsifying coins by an enemy of his, the bishop Bernard Saisset, who contested his authority. The infamy of being a "falsificatore di moneta", as this was often repeated in subsequent centuries, pursued the memory of the king and constituted a historical and moral background for many authors dealing with money. Around 1600, for example, the French publicist Jean Bodin (1593, VI/3:118) and the Spanish Jesuit Juan de Mariana (1609, chapter 10) recalled the infamous history of this king by way of Dante's judgement. Mariana emphasised the momentary victory of morality when Philip,

"at his death, repented his deed and told his son, Louis Hutin, that he had to put up with his people's hatred because he had debased the coinage, and that Louis Hutin, therefore, was to correct his father's mistakes and hearken back to old reckonings" (Mariana, 1609, chapter 10).

Several decades after Bodin and Mariana, Samuel Pepys, who authored an important diary of the 1660s in England, related a case of counterfeit coins that seems strange to today's readers. Visiting the Tower (the Mint), he was told the story:

"of one that got a way of coining money as good and passable and large as the true money is, and yet saved 50 per cent to himself; which was by getting moulds made to stamp groats like old groats, which is done so well that there is no better in the world; and is as good, nay better, then those commonly go; which was the only thing that they could find out to doubt them by $[\ldots]$ and then coming to the Controller of the Mint, he could not, I say, find any other thing to raise any doubt

\footnotetext{
${ }^{1}$ We thank the anonymous referees for their very helpful comments.

2 "Lì si vedrà il duol che sovra Senna / induce, falseggiando la moneta, / quel che morrà di colpo di cotenna.".
} 
upon, but only their being so truly round or near it." (Pepys, May 19, 1663, T.IV: 143-144)

Counterfeiters may thus issue better coins than the Mints, when the currency is of bad quality! ${ }^{3}$ In this case, the Master of the Mint, recognising his inability to preserve a quality currency, avoided punishing the counterfeiter:

"He was neither hanged nor burned, the cheat was thought so ingenious and being the first time they could ever trap him in it, and so little hurt to any man in it, the money being as good as commonly goes". (Pepys, id) ${ }^{4}$

Both cases of Philip the Fair and Pepys' counterfeiter spread confusion as to what should be considered false money. On one hand, the legitimate sovereign Philip IV The Fair was by no means a counterfeiter, as would have been an individual usurping the sovereign's right to mint coins. He simply used, and maybe abused, two of the basic monetary policy tools of his time: changing the legal value of coins ${ }^{5}$ and issuing new coins of a lower metallic content. On the other hand, it is clear that Pepys' counterfeiter usurped the sovereign's mark, like any other counterfeiter, whether he moulded coins of good or bad quality. While Philip IV seemed to have sovereign legitimacy in deciding the characteristics of the currency, he was explicitly considered a counterfeiter by Saisset and Dante; Pepys' counterfeiter on the other hand should have been sentenced to death because he usurped the sovereign's mark, and yet he was almost considered virtuous!

These two paradoxes raise a major question: beyond the two cases related above, how can we understand the diversity of the false money issues without restricting it to a counterfeiting problem, which obviously refers to crime? False money is more generally related to justice issues, in terms of criminality or not, and it is necessary to distinguish forms of unfairness induced by specific falsifications. False money is also related to legitimacy issues, so that one can consider the binary criteria true / false as depending on the legitimacy of the issuer's authority.

In this paper, we would like to clarify some issues about metallic currency falsifications mainly before the $18^{\text {th }}$ century. This subject, previously neglected, deserves a renewed attention in economic literature (see for example Caffentzis, 1989 and 2007; Sargent and Velde, 2003; Wennerlind, 2004; Schnabel and Shin, 2006; Valenze, 2006). We will not deal with the case of the forging of notes, that appeared mostly after that period ${ }^{6}$. We will adopt a broad definition of false money, which seems to have originated with

\footnotetext{
${ }^{3}$ Pamuk (2000) observes this paradox concerning the Ottoman Empire.

4 The counterfeiter's gain was due to the discrepancy already existing between the legal value and the metallic content of the degraded circulating coins. If one Crown should officially contain 1,25 oz. of silver, since there was a general clipping, the counterfeiter could -for example- produce two Crowns with this quantity of silver.

${ }^{5}$ For example, he cried up the silver groat from 13 to 39 deniers between 1290 and 1303.

6 As explained by Nussbaum (1950: 493), forgery was facilitated "in the era of paper money as mass falsification became easier, less expensive and more remunerative".
} 
individuals as well as political powers in parts of Europe. Then, a general claim to counteract counterfeiting may conceal a claim to suppress any possibility of debasing the currency. The false money problem was not only technical, but also -and maybe especiallypolitical. In order to understand this point, we aim at making monetary discourse clearer on the topic of falsifications, by analysing how three distinct authors mobilized specific theoretical grounds in order to solve this problem: the French Jean Bodin (1530-1596), the Spanish Jesuit Juan de Mariana (1536-1624), and the English John Locke (1632-1704). These three authors tried to define the rules of a fair government, defining the extent and limits of the political powers of their day, with Locke extending his reflection to the people's right to resist and Mariana even legitimizing tyrannicide. We would like to emphasize that, in the realm of monetary ideas, Bodin, Mariana and Locke had also some strong connections: as for them, the monetary power had to be restrained and, in order to protect the society against its excesses, boundaries had to be clearly defined. For these authors, the false money issue was above all a matter of justice. By the establishment of a hierarchy between distinct categories of false money, we will provide a relevant analytic framework that helps understand their arguments.

This paper states that one cannot understand clearly the general topic of false money if old texts are read with today's general definition of false money. A conceptual framework embracing diverse forms of falsification appears to be the basis for a clear assessment of primary sources and debates of the time. In section 2, we identify two primary categories of false money: the concept refers to counterfeiting -strictly speaking(by individuals) and to degradation of coins (by individuals, moneyers and officers of the Mint). In spite of repressive rules, condemnations of private counterfeiters were, for a long time, quite rare, and executing the punishment remained hypothetical. In the same time, money is not only a collection of objects, but an institution based on the trust the members of a society invest in it, as emphasized in section 3. In the discourses aimed at fighting counterfeiting by individuals, the issue was also (and sometimes especially) to counteract monetary manipulation. Hence, we deal with debasement and enhancement (by princes) as broader categories of false money. Then, we summarize the analysis by proposing a general scheme of false money. The symbolic and political dimensions of money are crucial for its acceptance, but what we could call "public faith" (following Bodin and Locke), that makes money unanimously accepted within a community, can sometimes collapse when a crisis arises. In section 4, we try to explain why the diverse forms of false money in broader sense may threaten the social significance of money (Wennerlind, 2004:131). We present a few monetary crises in Europe directly linked to the falsification problem, centring on three cases wherein three major authors exercised their pens: in France, a spiral of enhancement following rises in the voluntary price of the gold écu (Bodin); in Castile, the crisis of pure and debased copper coins, the vellón (Mariana); in England, the crisis in the quality of coins and the intense controversy surrounding the reform of the currency 
(Locke). The problem of money quantity was subordinated to that of money quality. Eventually, in section 5, we conclude on the 'monetary revolution' that led to a greater stability of the metallic monetary system. Until the end of the $17^{\text {th }}$ century, monetary instability and, consequently, mistrust of the currency, impeded the development of production on the long run, as understood by these three great authors. A stable monetary system was a requirement to a sound system of credit, being itself a condition to the spreading of industrial capitalism. Eventually, stabilizations, through a monetary revolution close to what had been proposed by Bodin, Mariana and Locke, occurred between the end of the $17^{\text {th }}$ and the beginning of the $18^{\text {th }}$ century.

\section{False money in a narrow sense}

Bodin, Mariana and Locke showed a common concern about the ability to debase the currency that led them to strongly affirm the necessity of a metallic system able to prevent any form of false money, be they operated by individuals or princes. There was then clearly a strong connection between falsification by individuals and falsification by princes and their administration. Hence, false money may take different forms that need to be distinguished when trying to take the complexity of this issue into account. Let us start with the three components of any coin, each one being opened to possible manipulation: an official coin under the metallic monetary system of the early modern period is made of a piece of metal, the mark of the sovereign, and a legal value expressed in the official unit of account. What will be considered "false money" in this text is an unfair manipulation of a combination of these three components, be it by individuals or princes themselves: raising the legal value, lowering the metallic content, counterfeiting the sovereign's mark. Divergent opinions on the borderline between fair and unfair manipulation can be readily found during the sixteenth and seventeenth centuries; this divergence is at the root of the ambiguity of the false money issue.

However, false money in a narrow sense, closer to the current representation, finds its expression in two operations whose definition and consequences call for further explanation: counterfeiting and degradation. Yet, starting with the idea of usurping a symbol, false money is extended toward situations of bad money, or coins of inferior quality.

\subsection{Counterfeiting}

When speaking today about false money, forgery, or counterfeiting, is what first comes to mind. Under the metallic monetary system of the early modern Europe, counterfeiting affected coins. Counterfeit coins were produced by individuals, organisations or princes not authorised by the sovereign Prince, whatever the quality of these coins. Consequently, the main distinctive feature of these coins was an usurpation of 
the sovereign's issuing rights, leading to a counterfeit of the sovereign's mark. Counterfeiters directly menaced the issuing privileges granted or acknowledged by the prince (acting for "the common good").

In that sense, counterfeiting was mostly operated by individuals seeking a profit by means of the gap between the current value of genuine coins and the output cost of counterfeits. Thus, beside the usurpation of the sovereign's mark, one can identify three other characteristics of forged currency: a disconnection between the legal value of the coin and the value of its metallic content, a lowered metallic content (obtained either by a lesser fineness of precious metals because light coins would be too easily identified, or by resorting to cores made of copper or bronze and plated), and a disconnection between the legal metallic content of the coin and its actual one.

The dynamics of counterfeiting could be related to that of debasement, as stresses Pamuk (2000) on the Ottoman case: forging new coins is an opportunity to make a profit, because of the temporary gap between the implicit value of metal given by the legal value of newly debased coins and the commercial value of that metal. Individuals rarely operated alone; organised networks were frequent, and they often operated from a foreign base. In Russia, for example, "the known techniques were numerous. Some produced stamps, others produced copper coins which were later coated with silver. Some even mixed tin or copper with silver right at the mint. Coins imitating the Russian coins were produced abroad, as well in early $18^{\text {th }}$ century such money was produced by the Danes, Swedes, and perhaps the English" (Raskov, 2007:13).

There were cases of counterfeiting by princes themselves, local or foreign. This must be distinguished from the tactics by which princes aimed at appropriating the quality and success of foreign coins by issuing their own coins featuring their own marks but replicating the metallic characteristics of a well-known and widely-used international coin: see the cases of local replications of the florin or the ducat in the later Middle Ages and the beginning of the early modern period (Nussbaum, 1950: 317). The case of kings ordering the issue of counterfeit foreign coins, thus seeking to destabilise the foreign state, seem to be rare in history. Late feudal lords seeking resources, in the context of a general lack of currency and sometimes of political unrest, came to issue coins directly imitating those of the king. Some produced coins inferior to royal ones, while others minted coins of good quality, but were nevertheless considered as counterfeiters by the king (see Bodin 1593, vol. I: 332-3, featuring such a case). At the same time, local monetary workshops minted exact replications of royal coins without being authorised to do so, thus collecting an undue seigniorage to the detriment of the king's Mint.

\subsection{Degradation}

Degradation, or any kind of abrasion, leads to coins of lesser quality because of the resulting decrease in their weight. The main consequence of degradation, and, when 
voluntary, its main purpose, are a gap between the actual metallic content of the coin and its legal content, as ordered by edicts. It thus contributes to the lowering of the metallic content, and to the disconnection between the legal value of the coin and the value of its metallic content. Degradation resulted from inevitable wear and tear of coins in their daily use, a situation which obviously did not involve fraudulent manipulation. But this involuntary and collective degradation produced a form of false money as well as voluntary degradation, that were clearly unfair.

Individuals degraded coins in order to collect the metal and, consequently, either bring it to the Mint (and get coins corresponding to the weight of the metal, minus the possible brassage and seigniorage), or sell it, or mint counterfeit coins by themselves. With this borderline case, one can see that degradation may be oriented toward the first case of false money seen above, and this was obviously serious enough to consider voluntary degradation a major crime. It took different forms: writers of the period often precisely detailed the modalities of degradation, including clipping, that appears today as the most prominent modality. Sargent and Velde feature sweating, clipping and shaving: "Sweating is an artificial form of abrasion in which the losses are collected, while clipping and shaving are outright removal of pieces of metal from the edges of the coin" (Sargent and Velde, 2002:346). Nussbaum talks about "clipping', 'washing' and other ways of 'lightening' genuine coins", as "more refined offenses" than "outright counterfeiting" (Nussbaum, 1950:40).

Whatever the modalities, and whatever their voluntary nature, degradation was sometimes so common that the currency was seriously deteriorated. Sargent and Velde cite an estimation of the consequences of wear and tear, showing something like 0.2 to $0.3 \%$ per year on English silver coinage, that is, between 10 to $20 \%$ loss of weight after 30 years (Sargent and Velde, 2002:346). Hence, degradation had important repercussions: the bad state of coins frequently compelled users to specify in every transaction the currency in which the payment would be made. This fuelled confusion and stimulated endless disputes at fairs or markets. The figure 1 (below) summarizes this first step of the analysis, showing the articulation between counterfeiting and degradation. Falsification may occur either through degradation, or through counterfeiting; and the latter requires the former. 
Figure 1 - False money in a narrow sense

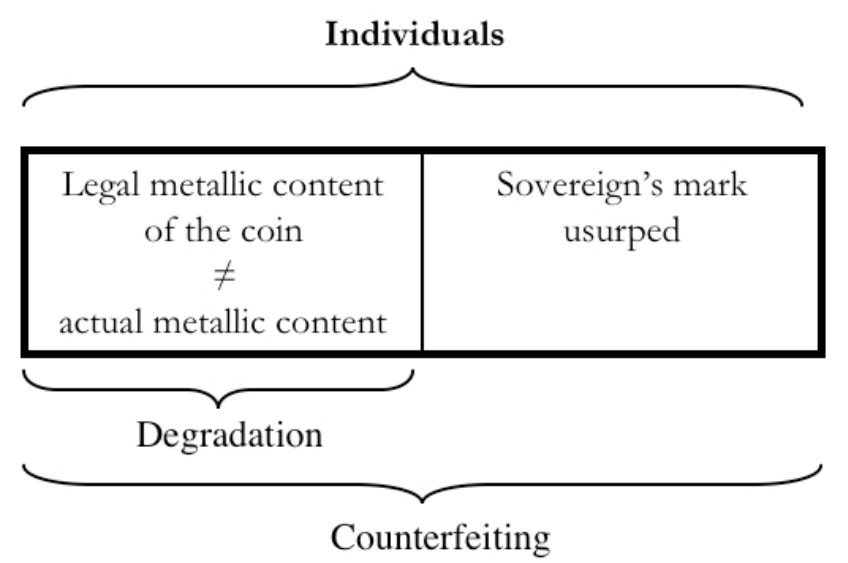

\subsection{Counterfeiting and degradation: between repression and tolerance}

One must stress the great danger induced by an uncontrolled spreading of counterfeiting and degradation of coins: trust in money was corroded, beginning with its first stage, the routine of daily uses. Clipping and counterfeiting were thus morally reprehensible acts, which demanded the revision of the legislation and the punishment system. But, whereas counterfeiting was, in principle, heavily punished, as well as voluntary degradation, we will record some examples of penalties, and try to explain why fraudulent operations were, in fact, often tolerated.

\section{Arguments against counterfeiting and voluntary degradation: from morals to repression}

Religious authorities took part in the prosecution of counterfeiters, who introduced suspicion and confusion into the society. In 1123, by the council of Latran, counterfeiters and " circulators of base coins » were declared oppressors of the poor, disturbers of the state and, therefore, excommunicated (in 1583, the council of Tours reiterated these sanctions) (Ruding, 1819, I:167). These questions were still discussed in churches at the end of the $17^{\text {th }}$ century, as evidenced by the Sermon against clipping by William Fleetwood in 1694 in England. For the bishop of Ely, clipping was not only illegal, but also "sinful", "as being a fraud upon every person" (Ruding, 1840, II:35). His Sermon addressed the case of false money in a precise and detailed manner. The bishop insisted on the fact that currency was founded on an act of faith: "For the Publick Faith engages, that every Man receiving a Piece of such a Mark and Denomination, shall receive in it so much Silver, and of such a Fineness" (Fleetwood, 1694:8). So, the moral code condemned private money-makers, who deserved to be punished by heavy penalties: "Clippers are as truly Thieves and Robbers, as those they find upon the High-ways, or breaking up their Houses, and do as well deserve their Chains and Halters." (Fleetwood, 1604:17). 
The question of false money was not confined to morals; above all, it was a legal problem: "The tradition of Roman law saw the right to mint as a royal prerogative and treated any infringement of this regalian privilege as a form of lese majesty or high treason." (Sargent and Velde, 2003:65) "In the Germanic laws the original punishment for counterfeiting was the loss of the right hand, a penalty also inflicted in England" (Nussbaum, 1950:40). By the Anglo-Saxon laws, "to this punishment, already sufficiently severe, the cruel policy of the Anglo-Norman Kings added loss of sight and emasculation." (Ruding, 1819, I:159) Punishments became more severe with the deepening monetization of European societies, "when the early economic system turned more monetary and the effects of counterfeiting were therefore more keenly felt" (Nussbaum, 1950:41); in France, as early as 1347 and for a long time afterward, counterfeiters could be boiled. In 1580, the Coutume de Bretagne specified: "counterfeiters will be boiled, then hanged" (article 634, quoted by Ménard, 2004). In England, during the 17th century, counterfeiting the King's coins was high treason, punishable by hanging (in the case of men) or burning (in the case of women). Punishments were slightly less barbarous from the Enlightenment onward, but death remained the major sanction (Nussbaum, 1950:42). In Russia, "Mint workers were made to kiss the cross, examined naked, tortured if suspected, prosecuted by means of pouring molten tin into their throats, punished with the severing of hands and ears, and with whippings. Some were even evicted from their houses and exiled to Siberia" (Kotoshikhin, 1859: 81, quoted by Raskov, 2007: 13).

Wennerlind (2004) showed that monetary policy not only included the issuing of money and the adjustment of its quantity, but also the execution of people guilty of tampering with the currency, and that this dimension was not marginal, but grew at the end of the $17^{\text {th }}$ century and during the $18^{\text {th }}$. Nevertheless, despite punishments established by law, there generally existed a noteworthy tolerance.

\section{Tolerance}

While various punishments threatened "money criminals", they were tolerated within the society. Counterfeiters were often persons of a high social rank, as Parsons (2003b) stresses: "Counterfeiting was something of an elite crime, requiring very considerable skills, capital and organization. Its practitioners tended to be goldsmiths (or locksmiths, who had the same engraving skills and were more often underpaid), merchants, members of the lesser nobility, or priests. (...) It was much less socially marginal than most criminality". This does not mean that they were accepted, but only tolerated to a certain extent.

Tolerance was all the more evident with clipping. Whereas clippers were considered criminals according to the law, often, in principle, to the same degree as counterfeiters, a lot of people in the lower ranks of society would clip coins that were already damaged (see 
Muldrew, 1996). Thus, traditionally, clipping was not seen as robbing other individuals, because everybody was involved in the degradation.

One important reason for such tolerance is that counterfeiting "lubricated" circulation by introducing specie, certainly not legal and whose value was not guaranteed, but which served to increase an inadequate money supply: "counterfeiters proved themselves economic agents whose function was to supply the market, while official coinages were defaulting. (...) Despite efforts to repress them made by kings, the need for specie was too big to examine closely their origin" (Feller, 1986). In cases of monetary tightening, degradation could avoid some major drawbacks: in England, for example, "a major depression and a collapse of credit, as happened in the 1590s, was averted because of the extent of clipping, as the clipped coins were, of necessity, increasingly accepted at face value." (Muldrew, 2001: 106) As a consequence of such needs, monetary uses were not confined to official coins (local and foreign). Thus the so-called Gresham's Law, reinvented in the 19th century", could be interpreted in a new light: "good" and "bad" coins circulated, and were accepted up to a certain point, unless public faith totally vanished (see below).

In England, these fraudulent operations were thus regarded as "unperceivable faults" until the years around 1690 and finally perceived rather positively by public opinion. "For the practice of clipping, pernicious as it was, did not excite in the common mind a detestation resembling that with which men regard murder, arson, robbery, nay, even theft. The injury done by the whole body of clippers to the whole society was indeed immense: but each particular act of clipping was a trifle.” (Macaulay, 1861, T.III: 389)

\section{Widening the scope: public faith and the false money problem}

In every society, legal punishment draws the line between legal and illegal practices, between what are to be considered "fair" and "unfair" acts. In the case of money, the situation was complex, because some illegal practices could be seen as bearable, during situations characterised by a currency shortage. But money is not only an object managed by defined authorities; it is a social medium. Thus, "counterfeiting challenged the general confidence in the exchangeability of money and consequently damaged the capacity of money to mediate exchange relations." (Wennerlind, 2004: 131). Money embodies public faith, a notion that must be examined.

\footnotetext{
7 In his History of Economics published in 1896, Macleod admitted: “ [...] in 1864 my friend M. Wolowski published the treatises of Oresme and Copernicus, by which it appeared that these great men had fully explained the matter 160 and 32 years respectively previous to Gresham, so that this great law, which is as well and firmly established as the Law of Gravitation, should be called the law of Oresme, Copernicus and Gresham” (Macleod, 1896:448; see also De Roover, 1949:91).
} 


\subsection{Trusting money: from a general framework to the case of the metallic system}

The traditional functions of money (means of payment, unit of account and store of wealth) cannot be carried out without trust in it (Aglietta and Orléan eds, 1998; Théret ed., 2007). More precisely, this general faith in money can be split into three levels, as featured in the following diagram (Théret, 2007).

Figure 2 - Three levels of public faith in money

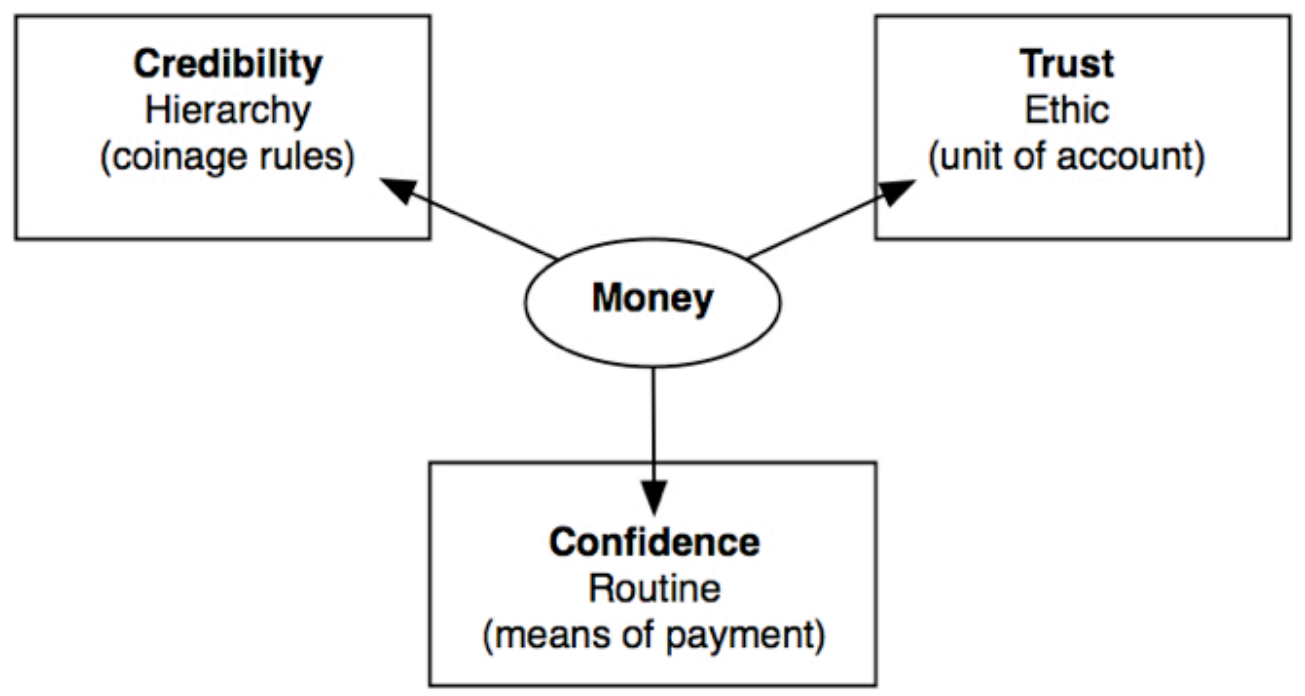

- Confidence, or routine faith, characterises the fact that money is routinely accepted as payment because everyone expects everyone else to accept it at face value. Routine in payments requires that the physical characteristics of coins are generally accepted and let people operate their transactions without having any doubt over their qualities and, more generally, over their acceptation by others. Monetary practices could thus develop daily without any major threats on the acceptability of the coins.

- Credibility, or hierarchical faith, means that money is accepted because the credibility of its issuers is certified by a legitimate representative of the payment community as a whole: today, central banks; in early modern Europe, Mints (Newton became director of the London Mint after the triumph of Lockean's monetary proposals) or sovereign monetary institutions (like, in France, the Cour des monnaies, which faced the opposition of Malestroit and Bodin as well). Credibility especially refers to the coinage rules implemented by the legitimate institutions.

- Trust, or ethical faith, ensures that money is accepted because it is created in accordance with the values and norms which provide the foundation of the community in which money is valuable. What is at stake here is a social recognition of the hierarchy of values established through the unit of 
account. From a pure symbolic viewpoint, coins bear symbolic representations or monograms of monarchs, monarchies and other transcending values (like, in 1683, the virgin Mary on new Castilian silver coins) that featured the unity of the huge diversity of economic operations and actors, introducing symbols of the community's unity into every monetary transaction.

Confidence, credibility and trust are thus three levels of public faith in money, whose combination ensures the stability of payment systems. The transcendent values of society are declined through the formulation of minting rules, and in the sphere of common payments.

As a basic consequence of such an approach, even metallic currencies contain a strong degree of fiduciarity (Andreau, Carré, Carrié et Lamouroux, 2007). In every system, the political, economic and legal levels need to appear coherent for each actor. Hence money is a pluridimensional medium, and public faith must be preserved to ensure the functioning of the monetary system. Operations such as recoinage or the punishment of counterfeiters could be seen as symbolic acts, aimed at ensuring either the refoundation or the permanence of the monetary system and the underlying social order ${ }^{8}$. Indeed, counterfeiting and degradation - but, as we are going to stress it, debasement and enhancement as well -, could threaten the credibility of the issuing authorities, as well as confidence in the daily routine of monetary practices, and trust in the overall values of the social order - three levels essential to every monetary system.

A comment on routine can be added: when the money system is so confused that counterfeiters are able to issue better coins than Mints (as in Pepys' case), anyone might accept counterfeit coins. This situation can be analysed in terms of a conventional pattern: "A medium of exchange - say, coin of the realm - has its special status by a convention among tradesmen to take it without question in return for goods and services. [...] the inconvenience of accepting a bad medium of exchange is less than the inconvenience of refusing it when others take it, or of taking what one can neither use nor spend." (Lewis, 1969: 48) But this kind of convention can nevertheless imperil the system.

\section{Counterfeiting, degradation and public faith}

Routine, hierarchy and ethics do interact: a "marginal" but continuously repeated act can undermine the whole society. As Caffentzis remarks, "theft is a one time affair, but the clipper's work introduces a continuous deepening obscurity into our reality and into our ideas." (Caffentzis, 1989: 28). An act considered a "trifle", because it only consisted of

\footnotetext{
8 For example, the prosecution of counterfeiters at the end of the $17^{\text {th }}$ century became performances in which "spectators, by their viewing of the scene, became adjuncts of the state in establishing - one can even say coercing - respect for and compliance with the rules of the monetary system.”, Wennerlind, 2004, p.149.
} 
the removal of a very small amount of metal, had huge social consequences. As it will be shown in the following section, Jean Bodin thought that counterfeiters perpetuated crimes of lese-majesté and, according to John Locke, armies of clippers were more dangerous than foreign battalions...

In other words, as Macaulay noted, "For great as the aggregate of the evil was, only an infinitesimal part of that evil was brought home by the individual malefactor." (Macaulay, 1861, T.III: 390). Addison, in his very interesting History of a Shilling of 1710, gave voice to a coin narrating its adventures, from the mines of Peru to the pockets of Londoners. The coin was eventually seized by a clipper who dismembered it: "I fell into the Hands of an Artist who conveyed me under Ground, and with an unmerciful Pair of Sheers cut off my Titles, clipped my Brims, retrenched my Shape, rubbed me to my inmost Ring, and, in short, so spoiled and pillaged me, that he did not leave me worth a Groat." (Addison, 1710: 187). This image is very fruitful. It was not only the petty coins that were dismembered, but the society as a whole. For example, if clippers exercised their craft on the English coin named Crown, clipping this coin meant eroding the King's representation, so "shaving, clipping, and filing the King's head stamped on the coin became a highly symbolic decapitation." (Wennerlind, 2004: 140). Clipping, filing or shaving coins could be seen not only as a fraudulent practice, but also (and above all) as a political act.

One index of the loss of confidence could be the intensification of clipping. When a crisis finally developed, the enduring tolerance stopped, as suggested especially by the case of England at the end of the $17^{\text {th }}$ century that will be briefly presented below.

\subsection{False money in a broader sense: debasement and enhancement}

There were other forms of falsification, which depended largely on the perception of princes' manipulation: while the king's arbitrage was recognised, allowing him to operate some manipulation of money, a subtle and changing borderline separated it from the purely arbitrary, a situation which generated debates and sometimes led the sovereign to be considered a falsifier.

\section{The confusion around 'debasement'}

The very general term 'debasement' is highly ambiguous, since it takes on different meanings, even among current economic historians. Making the position clearer, as did for example Gould (1970), Sargent and Velde (2003) or Fantacci (2005) involves refusal of this loose sense. Gould (1970) actually distinguishes three practices: a) reducing the weight of coins; b) reducing the degree of fineness of the gold (or silver)/alloy mix from which they were struck; c) tariffing the coins at a higher valuation in terms of money of account, while leaving their physical characteristics unchanged. According to him, 'debasement' strictly speaking corresponds to case (b), while (c) characterises 'enhancement'. The first method, 
(a), was simply called 'making the coins lighter'. It must be said that, in its loosest meaning, 'debasement' comes to refer to these three methods!

This is why it is more relevant to consider cases (a) and (b) as debasement processes, i.e. the act of decreasing the precious metal content of the coin, as ordered by the prince, by minting new coins, either of lower fineness of the precious metal that constitutes a coin (gold or silver being mixed with a base metal, generally copper) or of lower weight. A clear distinction must be made between enhancement (or cry-ups, ie a rise in the legal value of unchanged coins ${ }^{9}$, case $c$ ) and debasement (minting new coins of lower metallic content ${ }^{10}$, cases $a$ and $b$ ).

\section{Debasement strictly speaking}

Debasement was carried out by princes. The main purpose and consequence of debasement was the appearance, or more generally the development, of a gap between the legal value and the value of the metallic content evaluated in units of account through legal prices of metals. Whatever the gap, it had to be greater than the brassage (a fee charged by the mint operator to cover production costs, excluding the price of metal); it depended mainly on the seigniorage decided with the coinage. Debasements were generally carried out officially, the characteristics of the new coins being published, especially when old coins were taken out of circulation in order to melt them down and issue new coins of lower precious metal content.

There were nonetheless borderline cases involving hidden debasement. Princes could indeed order a debasement without announcing that the newly issued coins were debased. This was the case of Swedish King Gustav Vasa during the 1540s (Ögren and Runefelt, 2010). But princes did not always control the process. For example, officers of the Mint sometimes committed mistakes in the application of edicts. More disturbing were cases of officers of the Mint, or moneyers themselves, ignoring edicts and voluntarily issuing coins of lesser metallic content. As well as clipping and other forms of degradation, hidden debasement generated a gap between the actual metallic content of coins and the legal one, as ordered by the royal edicts, whatever the official quality of the coins.

\section{Enhancement}

Enhancement was the most widely used tool of monetary policy, since, in the metallic monetary system of medieval and early modern Europe, where coins did not bear

\footnotetext{
9 Though this is of old use, Sargent and Velde (2003) prefer to use 'cry-ups' when referring to what we will call here 'enhancement'.

10 One can note that the definition is far from being neutral. For example, French terms referring to enhancements or cry-ups are frequently translated in English as debasement loosely speaking, thus inducing misunderstandings. Similarly, the English translation from Latin may produce some confusion (see discussion on Mariana, below).
} 
any mention of their legal value, it was very easy to change them by an edict. Like debasement strictly speaking, as well as degradation and counterfeiting, enhancement produced a gap between the legal value and the metallic value of a coin; but it did by no means affect the metallic content. For this reason, the practice may appear less harmful and unfair than debasement, in which the intrinsic value of the coin may be heavily affected.

\subsection{Debasement, enhancement and Public faith}

While counterfeiting and degradation were morally and legally condemned, although tolerated to a certain extent, debasement and enhancement could not be legally condemned, since they were ordered by princes themselves. They were nonetheless generally morally condemned, since they undermined public faith.

In a metallic monetary system, the pact between the prince (who can dictate the issuing rules, such as the relationships between the unit of account and the means of payment) and his subjects could be easily manipulated. It is widely known that princes were in the habit of devaluing the standard: in the long run, every European country experienced a steady depreciation of its currency. For example, Cailleux (1980) and Aglietta (2006) calculated that in 1789, the French livre tournois represented 3,6\% of its gold value of 1266, while the 1793 English pound sterling amounted to $35,7 \%$ of its value in 1278 .

The steady lowering of the metal content of the circulating medium endangered private contracts: creditors could be concerned about the means of payment used to redeem debts. If the prince ordered an enhancement between the loan and its repayment, the creditor could receive less metal than he had lent. The problem could be worse in the case of the withdrawal of existing coins and the issuing of new coins of a lesser metallic content, but this was less frequent. In response to the risks and the confusion induced by such practices, grew networks of bills of exchange in Europe from the $15^{\text {th }}$ century, as well as autonomous and transnational systems of account, as ways to erect parallel systems of account aimed at preserving commercial contracts from enhancement and debasement (see Boyer-Xambeu, Deleplace, Gillard, 1994).

According to Robert Cotton, "The Regulating of Coin hath been left to the care of Princes, who are presumed to be ever the Fathers of the Common-Wealth." (Cotton, 1626, in Mc Culloch, 1856: 127). But when the sovereigns manipulated "their" currencies too frequently, public faith was endangered, in its three monetary dimensions featured in figure 2 above. Before developing this point below by means of the analyses of Bodin, Mariana and Locke, another quotation from Cotton can summarise a contemporary point of view on this subject: "The Measures in a Kingdom ought to be constant: It is the Justice and Honour of the King; for if they be altered, all Men at that instance are deceived in their precedent Contracts [...] for no Man knoweth then, either what he hath or what he oweth." (Cotton, 1626: 138) 
When the tolerance of coins of inferior quality was no longer bearable, situations could lead to important crises, and the powers had to reaffirm their authority, by new definitions or legal measures that tried to restore confidence, credibility and trust. Crises generally led to recoinages ${ }^{11}$ : these operations were not only a necessity after generalised counterfeiting and clipping, but are to be understood in the framework of rethinking the quality of the official coinage. These moves towards coins of better quality were seen as huge operations aimed at restoring the integrity of damaged coins, whereby fire purified bad currencies ${ }^{12}$.

\subsection{The four categories of false money}

Figure 3 summarises the four categories of false money we previously identified. There is obviously a moral, as well as an economic, hierarchy among these forms. Each false money category is associated with a main distinctive feature - although we have to keep in mind that all but the counterfeit of the sovereign's mark appear in at least two categories. The figure must then be read as follows: as we progress from the left to the right, a category of false money cumulates features of former categories and includes a new one. For example, the metallic content is lowered as a result of all of these manipulations but enhancement. On the top appear the operators of each sort of false money: either princes, including their monetary administration (moneyers and officers of the Mint), or individuals.

Falsifications are considered more unfair as we progress toward the right, since they are obviously more cheating and misleading the people, losing any justification especially related to sovereignty. Moreover, falsifications are viewed as harmful since they introduce trouble into routine payments and accounts. Economic harmfulness of falsifications depends on the quantity of degradation and counterfeiting operated, and the frequency and the quantity of enhancement and debasement operated by princes.

By all means, there is a qualitative gap between the categories related to prince's manipulation and those related to individual practices. Building such a chart, gathering individuals' cheating and prince's manipulation, serves to understand the continuity and hierarchy between those acts, as considered by various authors of the early modern period.

\footnotetext{
11 Recoinages could also be implemented after a technical improvement, as the French recoinage of 1640, decided immediately after the implementation of the mill technique of minting, that allowed to "produce a fluted, unclippable edge" (Appleby, 1978: 228).

12 In his History of a Shilling, already cited, Addison recounted the recoinage operations from the point of view of the coins themselves: "[...] when every Body thought our Misfortune irretrievable, and our Case desperate, we were thrown into the Furnace together, and (as it often happens with Cities rising out of Fire) appeared with greater Beauty and Lustre than we could even boast of before.” (Addison, 1710:187).
} 
Figure 3 - Four categories of false money

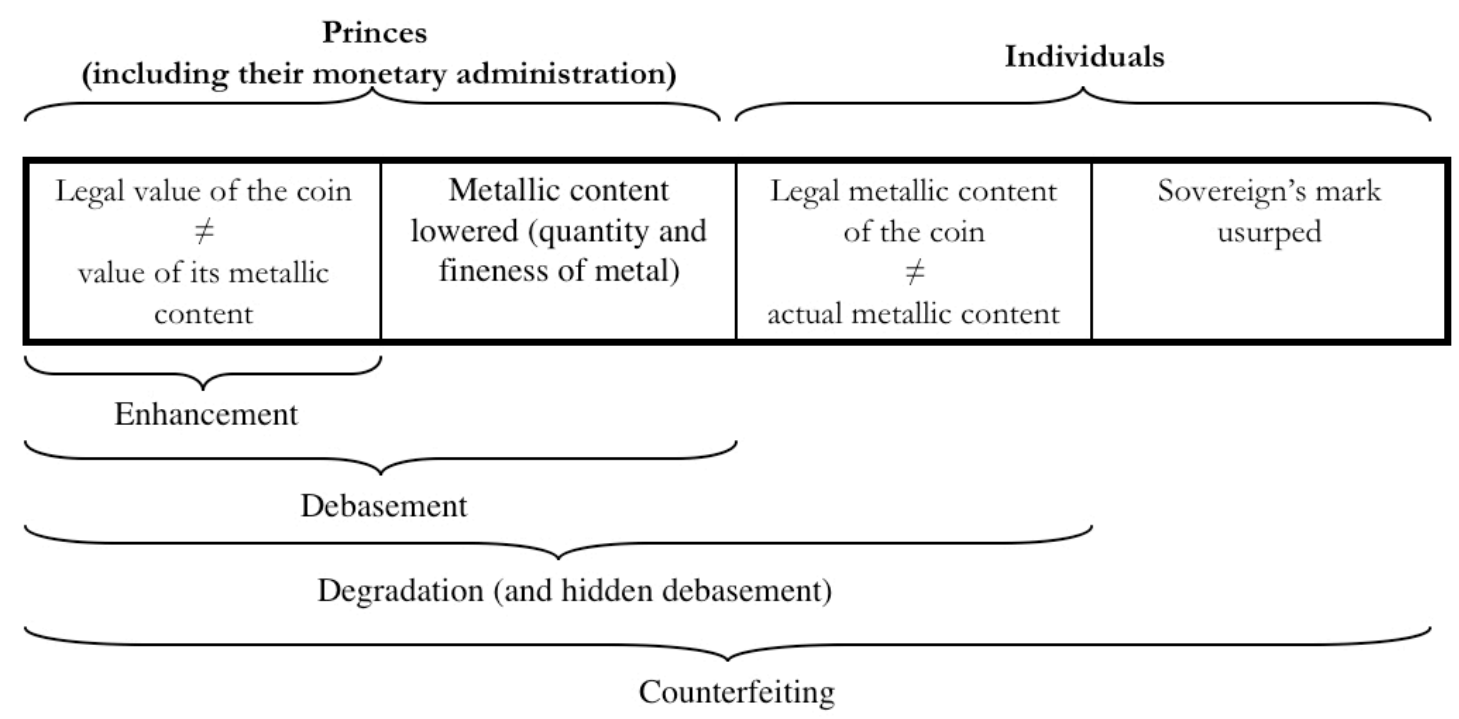

\section{Converging analyses from distinct maelstroms of falsification: Bodin, Mariana, Locke}

The monetization process of the early modern period was carried out within the framework of a metallic monetary system, including full-bodied coins (mainly made of silver, but also gold and sometimes copper, as in Sweden and Spain during some periods) and types of billon coins (small change whose current and legal prices could not be justified by their intrinsic metallic content which was very poor). Since the tools of monetary policies were mainly limited to manipulation of the legal values of coins, of their metallic content, and of the quantity of coins to be issued, every part of Europe faced false money problems, whatever their nature. Actually, the false money problem was not only technical (a matter of minting techniques); it was economical (a matter of economic troubles), moral (a matter or fairness and justice) and eventually political (a matter of sovereignty). Moreover, contrary to the position frequently held in historiography, most debates concerned not so much the quantity of coins as their quality. This is reflected in the numerous publications and controversies dealing with this problem.

Putting aside various interesting cases of monetary crises where falsifications played a major role, as, for example, the Kipper- und Wipper Zeit in the Holy Roman Empire (see for example Kindleberger, 1991), we will emphasise three examples linked with three major authors of their time whose writings were related to the falsification context (broadly speaking, as defined earlier in this paper): France, with Bodin's writings; Spain, with Mariana's texts, and England, with Locke's proposals. Our purpose is not to be exhaustive, 
neither on European cases, nor on debates and writings generated by specific situations experienced by a couple of countries; it is, rather, to assess to what extent such contexts were analysed by distinct authors on their specific theoretical grounds, giving place to possibly similar proposals. What is especially interesting is the articulation these authors established between false money forms. We will see that the formerly distinct problems, namely, on one side, clipping and counterfeiting (mainly by individuals), and, on the other side, debasement and enhancement (by princes) were intimately related. One important lesson that surges from this insight is that monetary thinkers in the context of metallic system were less interested in the money quantity problem than in its very quality, and that the quantity issues were subordinated to the quality ones.

\subsection{Jean Bodin and the French monetary crisis of the $1560 \mathrm{~s}$ and $1570 \mathrm{~s}$}

In France, a series of enhancements occurred between 1560 and 1577, a period characterised by a dramatic rise in prices. Successive cry-ups did not manage to stop the dynamics of rising voluntary prices for the main gold coin, the écu, fostered by the outflow of good coins and the inflow of bad foreign coins. The legal price of the gold écu rose from 46 sols in 1560 to 70 sols in $1577^{13}$. The deepening crisis was eventually stopped by an important reform implemented that year, especially formalized by Thomas Turquam and implemented by the Cour des monnaies (Parsons, 2003a). It unified the currency and the unit of account, putting the gold écu in the centre of the monetary system at a fixed price of 60 sols. This new system lasted 25 years.

In 1566, Jehan Cherruyt de Malestroit, officer of the Chambre des comptes, published his analysis of the general rise in prices that was provoking a growing general dissatisfaction. Malestroit combined two paradoxes. First, the general perception of prices rising sharply was nothing more than an "image of account", i.e. a monetary illusion caused by enhancements. Prices rose indeed along with cry-ups, which meant that anyone did not pay things with more metal than before. Second, a rise in the price of the coin impoverished people whose incomes were fixed, since they received less metal.

The controversy that arose in 1568 with the first answer from Jean Bodin (15301596), a jurist and lawyer of relatively low status, is commonly viewed as a pioneering moment in the quantity theory of money. Actually, the debate developed throughout the 1560s and 1570s and various secondary authors participated (at least the following: on an independent basis, La Tourrette, Colas, Turquam; supporting Bodin's position, Girard du Haillan; supporting Malestroit's position, Garrault). Bodin discussed only the first paradox of Malestroit, particularly analysing the causes of the rise in prices. Two of those causes were monetary: (1) the abundance of gold and silver, and (2) the price of the coin. While the second one is the argument developed by Malestroit himself, the first argument is a

\footnotetext{
13 The French unit of account, the livre tournois, consisted of 20 sols.
} 
new one. Today's economists frequently acknowledge Bodin $(1568,1578,1593)$ as one of the first authors clearly exposing what would become the quantity theory (O'Brien, 2000), but there is no consensus on that point (Arestis, 2002; Blanc, 2007). Anyway, Bodin's monetary ideas should not be reduced to such a theory, at least because the very core of Bodin's monetary analysis has to be found in his reflection on the conditions wherein monetary sovereignty should be fulfilled and limited (Blanc, 2006, 2007).

Such an analysis suggests, thus, that the controversy calls for other interpretations, where false money issues are given a central role. Whereas Malestroit centred his analysis on enhancement, Bodin not only included both enhancement and debasement by the Prince, but also degradation operated by officers of the Mint, counterfeiting and clipping by individuals and foreign specie of bad quality.

Clarifying the common view on false money by showing its underlying logic allows one to better understand the debates of the time. For example, it allows one to understand that the controversial debate on the royal ability to debase the currency can be hidden by a general and unanimous denunciation of bad coins applied to the special cases of counterfeiting and bad foreign coins, thus formally lessening the sovereign's responsibility. ${ }^{14}$ Moreover, some stress the necessity of battling against counterfeiting, arguing that it is an impediment to the supremacy of royal minting. The suspicion towards coins was nourished by the thin boundaries existing between true and counterfeit coins, on one hand, and, on the other hand, good and degraded or debased coins. All these concerns finally relate to a dichotomy between good and bad currency.

These general debates found expression in proposals. In most cases, however, they were related to the false money issue only partially, proposing a combination of some of the following: severe sanctions against counterfeiters; a change in minting techniques, making counterfeiting more difficult; a change in the definition of the metallic content of the coins; or a strict prohibition of the use of foreign coins. Nevertheless, the issue of the royal ability to debase remained a very difficult one; Jean Bodin tried to resolve it. His proposals were intended to definitively avoid all forms of false money. We suggest that herein lies the real importance of Bodin in the history of monetary ideas.

The originality of Bodin's monetary analysis lies in its relationship with the core concept of his works, sovereignty, developed in his major work Les Six Livres de la République. Given Bodin's interest in the development of this concept, counterfeiting by individuals should be a much more serious issue than bad coins induced by the Prince's debasement, since counterfeiting usurps the mark of the sovereign and constitutes what Bodin called a crime of lèse-majesté. Arguably, bad currency makes it difficult to get stable

\footnotetext{
${ }^{14}$ See for example Bouteroue (1666: 7-9). He defines counterfeiters as those who clip, wash and use other inventions in order to debase coins; but the main causes of debasement that he identifies later all proceed from the king's practices.
} 
references in prices, which undermines commercial activity. Nevertheless, it is by no means in contradiction with sovereignty, since sovereignty implies a right to debase. On the same ground, the recurrent circulation of foreign coins (of good and bad quality) should be viewed as necessarily hurting the principle of sovereignty.

Yet, Bodin's analysis of money puts falsification first, in the broad sense we previously identified: he focused his attention on the quality of metal, not on the mark of the sovereign. Indeed, the very existence of both counterfeit coins and debased coins proceeded from the same logic: profit, resulting from the difference between the legal value of the coins and the minting costs. Counterfeiters certainly diverted the mark of the sovereign, but their only purpose was to make a profit by falsifying the metallic content of the coins they minted. Fighting the falsification of the sovereign's mark (on the counterfeit coins) was thus subordinated to the fight against the falsification of metal (on debased and degraded coins). The reversal of Bodin's analytical framework, putting the principle of sovereignty second when reasoning on money, applied too to the problem of foreign coins. Bodin worried about this problem when their metallic content was of a lower fineness than that of the domestic coins: those bad coins could flow in to be exchanged for good French ones, which would be melted and exported. Good foreign coins did not create such a problem (Bodin, 1568: 134 and 137-8). Despite his theory of sovereignty, Bodin was more troubled by this risk of an inflow of bad coins than by the symbolic contradiction brought by foreign currencies to the royal mark. Other French writers after him would be more worried by this symbolic issue — for example Montchrétien (1889 [1615]). Finally, Bodin, like other contemporary monetary writers, with the exception of Turquam (1573), did not analyse the effect of the high prices of foreign coins on the price of the domestic coin.

The contradiction between Bodin's interest in the construction of sovereignty and the acceptance of something apparently challenging monetary sovereignty may be understood through the distinction between minting and circulation, regarding monetary matters. From a minting point of view, the authenticity of the mark is a peremptory necessity, the quality of the metal being a secondary issue. From a circulation point of view, Bodin reversed this order: the mark is nothing more than secondary, and the metal becomes the central point, the conditions in which economic activity is carried out being related to it. Consequently, it appears that the false money issue leads to a particular combination between, first, the three components of coins (metal, mark and legal value) and, second, the two phases of coins (minting and circulation). A strict sovereignty point of view would lead to bring up the issue of the mint and the mark, whereas an economic point of view would lead to bring up the issue of the metal, the legal value and the circulation. It is noticeable that Bodin constructed a theory of sovereignty with a monetary dimension but, in order to resolve the false money issue, deeply related to sovereignty, he 
took up the economic point of view and then stressed the circulation, legal value and metal issues.

The core problem was then, according to Bodin, the design of a sound and stable system that definitively prevented debasement by the Prince. Suppressing the features of the official monetary system which made the use of metal of low fineness possible would be the ground on which it would be possible to completely overcome the crime of lèsemajesté stemming from counterfeiting, as well as debasement and enhancement by the Prince and all forms of degradation.

Bodin's proposals led to a monetary system made up of good coins only, whatever their origin. He proposed a system organised with full-bodied coins (of gold, of silver and, depending on the version of the proposal, of copper) and an immutable legal value of the coins equal to their intrinsic value (Bodin, 1593, book VI, chapter 3). He proposed to demonetize foreign coins of lower quality and to prohibit the export of good coins. He also proposed reforms in minting rules and techniques, so that counterfeiting would become technically impossible or too difficult. This last point was not specific to Bodin, since other writers or officers of the Mint were also looking for such results ${ }^{15}$. The French monetary reform of 1577 did not take Bodin's proposals into account. One of its weaknesses lied in the idea of a fixed ratio between gold and silver (1:12), as noted by O'Brien (2000): it is enough to destroy all the system. Indeed, changes in the current ratio due, for instance, to the inflow of more silver than gold as it appeared before and after Bodin's writings, leading to a change in the ratio in favour of gold, would induce flows of coins consistent with Gresham's law.

\subsection{Juan de Mariana and the early beginnings of the vellón crisis}

In 1609, the Spanish Jesuit Juan de Mariana (1536-1624) published a short "Treatise on the Alteration of Money"16, which may be assessed as an important milestone in the evolution of monetary ideas. It must be said that Mariana's reputation, both contemporary and posthumous, came primarily from other books, the Historice de Rebus Hispanice (History of Spain, 1592) and De Rege et Regis Institutione (On the King and the Institution of Kingship, 1599). In the latter, which was to serve as a guide for the young Philip III, he developed his view of a constitutionalist monarchy. He came to argue that tyrannicide is fair when there is no other solution to put an end to the devastation of an unjust king: "any citizen, in the name of the people, has the right to kill the tyrant" (Part I:6). His description of the tyrant does not directly refer to possible misuses of money, but includes the idea of

15 This was the case, for example, of Nicolas Briot (1615), during the first two decades of the seventeenth century, before he crossed the Channel to offer his services in England.

16 The original Latin text, entitled De Monete Mutatione Disputatio?, is part of a much larger book that contains several parts, the Tractatus Septem. An English translation of the only "treatise" was published in 2002 in the Journal of Markets and Morality; we use this translation in the quotations of the present paper. 
ruining his subjects and exhausting them so that he cannot enforce more taxation. In the same book, Mariana denounced adulterations of the currency as a form of taxation (Part III, chap. 8, "De Moneta").

Ten years later, his short essay on money mainly dealt with debasement and, with less insistence, enhancement, considering however that they differ little (chapter 11) ${ }^{17}$. Mariana wrote this essay in reaction to the new monetary context of Castile, characterised by new issues of pure copper coins, known as vellón. Issue of vellóns with a very low silver content started in 1597, then two years later new vellóns could be made of copper only. This was the beginning of a long history of small change crises in Castile and recurrent debasement, ending only in the 1680s (Font de Villanueva, 2006; Jefferies, 2010). Yet, as Jefferies (2010) states, Mariana analysed the situation induced by the new vellón issues in a theoretical manner, anticipating crises, rather than reacting to situations of open crisis, given that such a crisis developed progressively. Vellón crises occurred especially around 1628 and 1642 with a maelstrom of manipulation of the coin. Although not formulating it so directly, Mariana's central point was then falsification by princes themselves. Counterfeiting was considered a sub-product of princes' falsification, for the disconnection between the legal value of the coin and the value of its metallic content made it possible for individuals to forge coins of a lesser quality and return a profit on them.

Mariana stated that a king, not owning his subjects' goods but protecting them unless he is a tyrant, could not create new taxes or raise existing taxes without their free consent through a consensus. Debasing money without the consent of subjects, $i e$ reducing its intrinsic value through its weight or its quality, as well as enhancing its value, is then robbery and an "evil". According to Mariana, only "pressing circumstances" such as war or siege may legitimise debasement without the people's consent; but should be reverted as soon as peace has been restored. Money, as well as weights and measures, is at the very foundation of commerce; "they cannot be changed without danger and harm to commerce". What is interesting is that Mariana's arguments against debasement and enhancement were less moral than economic - even though morals were an important part of his general reflection, as a theologian who referred to natural law.

According to Mariana, money has "a twofold value" (chapter 4). One is "intrinsic and natural"; it comes from its metallic content ("its type of metal and its weight", plus "the cost of labor and equipment in minting", ie a brassage including a provision for depreciation). The other is "the legal value", it is "extrinsic, inasmuch as it is established by

\footnotetext{
17 The original Latin title was more explicit than its English translation: dealing with monetae mutatione, it referred to general changes in the currency, i.e. both enhancement and debasement. The variety of the Latin words originally employed by Mariana, "mutatione" (a change, that is not necessarily bad), "vitio" (corrupt, alter) and "depravatio" (corruption, alteration) are not systematically rendered, and the English words "debasement" and "alteration" used in the translation may refer to any of them.
} 
the law of the prince, who has the right to prescribe the worth of money as well as of other goods". In Mariana's ideal system (corresponding to a "well-constituted republic"), these two values should be equal and not differ: "they must be mutually adjusted if we want things to be sound" (chapter 11). He includes in this reflection the possibility of a small seigniorage raising the value of the coin slightly higher than its "intrinsic and natural value". This makes a difference with Bodin's ideal, where no seigniorage and no brassage should be added to the intrinsic value.

Mariana was primarily concerned by debasement of small change. He starts by detailing the advantages resulting from such debasement, beyond the ability to finance the king's expenses (chapter 7). The main advantage of debasement is its capacity to speed recovery of the economy when it is ordered in a situation of currency shortage. He then discusses, and refutes, several minor disadvantages derived from debasement (chapter 9), and states that a pure copper coinage could be good, since its legal value is adjusted to its intrinsic one. The major disadvantages are then explained (chapter 10), in the Castilian case where more issues were ordered than authorised by law. Firstly, debasement and enhancement are "against right reason and the natural law herself - it is a sin to change them". Secondly, this money change generated a general inflation. Mariana firmly states that inflation is an inescapable consequence of any alteration in coinage, since the price of commodities increases "to the degree that the coins have been debased or the value of the coins increased". Thirdly, debasement generates trade difficulties; yet trade is the "foundation for public and private wealth". All this generates unintended disastrous consequences: whereas the king aimed at raising his wealth, he only gets more poverty, far from the initial purpose; and, ultimately, the greatest disadvantage is "the general hatred that will be stirred up for the prince".

It is clear, then, that debasement and enhancement of small change (copper vellóns) has to be avoided, for economic and moral reasons. Mariana then discusses the case of silver and gold money. The disadvantages previously analysed are the same for these coins, but their overall effect depended on the extent of the use of these coins. Since "silver is the backbone of commerce", the effects of silver debasement and enhancement would be far-reaching: "when it is altered, everything else resting upon it will necessarily collapse" (chapter 11). Mariana shows the turmoil that the mixed circulation of silver coins of distinct intrinsic values would produce. On the contrary, the falsification of gold coinage would produce little effect because gold was used far less often.

Mariana thus concludes that "If such is done, without consulting the people, it is unjust; if done with their consent, it is in many ways fatal" (chapter 13). Mariana's treatise ends with a bitter attack against corruption. As a consequence of his strong positions, he was condemned for the charge of lèse-majesté. He was sentenced to imprisonment and was finally confined for years to a Franciscan convent. The Spanish crown intended to 
destroy the entire edition of the book throughout Europe (Jefferies, 2010, quoting Beltrán, 1987). The essay, joined to another treatise simultaneously published in the same book, was placed on the Index Expurgatorius; some years before, his De Rege had been listed on the Inquisition's Index - to which he had collaborated ten years earlier.

\subsection{John Locke and the great recoinage}

Locke's major works upon the theory and practice of the political power (his Treatises of Government) were written prior to the Glorious Revolution (Laslett, 1970; Ashcraft, 1986). Theorizing sovereignty and defining the limits of powers, these treatises greatly influenced the new English regime. According to Locke, communities are created by an "agreement", and the government established by "Politick Bodies" should never be arbitrary. Arbitrary decisions, or "incroachments [...] prejudice or hinder the publick good” (Locke, 1689, \$163:394). In his Second Treatise of Government, the philosopher clearly stated that "the Legislative being only a Fiduciary Power to act for certain ends, there remains still in the People a Supream Power to remove or alter the Legislative, when they find the Legislative act contrary to the trust reposed in them." (Locke, 1689, \$149:385). Locke's subsequent influential advices on monetary policy (1691 and 1695) must be seen in conjunction with the political architecture he had designed. In both cases, the role of trust is of paramount importance: for the philosopher, political and monetary trusteeships were closely articulated. But, during the Glorious Revolution, the "fiduciary power" of the English currency fell at a very low level, and trust in monetary instruments vanished almost completely. Indeed, while the war opposing Great Britain with France was prolonged after 1689, a severe monetary crisis burst (the war broke out after James II had to flee to France and was replaced by William of Orange).

During the 1690s, the scale of the clipping exerted on hammered coins increased extremely quickly: the discrepancy between the legal weight of the coins received in payment for taxes and their real weight went from $12 \%$ in 1686 to $24 \%$ in 1693, then to $55 \%$ in 1696 (Kelly, 1991)! The ordinary silver coin was found to contain one half the weight of silver it was supposed to contain. This increasing zeal of falsifiers was a major indication of a deterioration of faith in the English payment system. A debate took place: a Treasury official, William Lowndes, wanted to "raise the coin", i.e., to increase the extrinsic value of the silver coinage. Lowndes' arguments did not convince the opponents ${ }^{18}$ of what consisted in a depreciation of the pound sterling, notably those who sat in the government. These latter listened to different advice, and Somers (Lord keeper of the Seal) urged Locke to publish a work criticising each point of Lowndes' proposals and pleading for a general recoinage. Locke thought that coins possessed a natural value, which legislators and kings had to respect. Locke denied the fact that money was a political creation and insisted "on

\footnotetext{
18 "His ultimate objective was to clear the way for new war loans", Kleer (2004:553).
} 
the sacrosanctity of the monetary standard"19. Thus its value could not be modified in a mindless way, and the public authority had to protect its stability. In any case, the source of monetary disorders was to be found in the proliferation of misdeeds.

According to Locke, an enhancement would assimilate the State to a counterfeiter, because it would sell a lesser quantity of metal under the same name. "Raising the coin" would "rob all Creditors of One twentieth of their Debts, and all Landlords One twentieth of their quit Rents for ever" (Locke, 1691:309)20. Stamping coins, one of the sovereign acts par excellence, guaranteed the smooth carrying out of payments, hence the King could not manipulate the standard at will. The strength of this position which "naturalised" money laid in its capacity to transcend the opposition between Whigs and Tories and to reconcile the point of view of the creditors and the land-owners. On the other hand, debtors and the lower classes were intended to pay the price of the reform promoted by Locke, their debts being revalued. "[T] he use and end of the public stamp is only to be a guard and voucher of the quantity of silver which men contract for; and the injury done to the public faith, in this point, is that which in clipping and false coining heightens the robbery into treason" (Locke, 1695:415). The counterfeiters' search for profit not only constituted a theft ${ }^{21}$, but a case of high treason. "For what was at stake was not simply an economic proposition, but social subversion" (Caffentzis, 1989:35). The monetary crime exceeded widely the scope of the traffic of precious metals: it affected the very foundations of civil society. "Clipping is the great Leak which for some time past has contributed more to Sink us than all the Force of our Enemies could do. 'Tis like a Breach in the Sea-bank, which widens every moment till it be stop'd." (Locke, 1695:472)

The philosopher reasoned both in terms of the ethical and routine levels of trust in money: clippers undermined the social contract because they attacked the representation of the State, while the King should avoid every alteration. As Locke asserted, monetary policy must strengthen faith because "Altering the Standard [...] will weaken, if not totally destroy the publick Faith" (Locke, 1695:417). So the authorities should insure that the circulating medium was perfectly fitted to the standard: it was thus wise to practise a general recoinage, even at the price of deflation. To summarize, "The clippers were more serious enemies of the state, in Locke's view, than the French regiments at Namur» (Caffentzis, 1989:43). Assimilating mere clipping to a crime of high treason towards the Commonwealth ensured the monopoly of the state by effectively punishing such a crime by capital punishment.

\footnotetext{
19 See Appleby (1978: 64) and Kelly (1991: 29).

20 «Creditors and Landlords: the classes to which Locke himself belonged, and whose interest, particularly that of the landlords, he tended to equate with that of the state.», Kelly (1991, vol. II: 443). See H. Layton, Observations concerning Money and Coin, 1697, p.13, cited par Appleby (1978: 58).

21 "Clipping by English Men is robbing the honest Man”, Locke (1695: 417).
} 
Eventually, William III, concerned with the restoration of the honour and the prestige of the nation, supported Locke's conclusions. Under his impulse, Recoinage Acts were promulgated. Hammered, clipped and false silver coins were to be melted and recoined (milled) ${ }^{22}$. After May 4 1696, clipped coins were no longer legal means of payment. In 1696 and 1697, counterfeiters constituted the daily concern of the government. The pursuit of offenders had to be carried out effectively. This task fell to the Mint. In 1696, Isaac Newton was appointed Director of the Mint, of which possessed judiciary powers. From the time of his arrival, he had to pilot the modalities of the recoinage, that was, the organisation in the entire English territory of the reception then the reintroduction of coins. Two Acts preventing counterfeiting were passed in 1696 and 1697 by which the prosecution of the cheater was expanded, so any proven appropriation of the privilege to mint coins really exposed perpetrators to capital punishment. Abandoning his scientific research, Newton set himself the task of fighting counterfeiters with unequalled zeal. He personally collected information concerning suspects and pursued them, which led to the execution of many offenders" ${ }^{23}$. "Newton became the detector, interrogator and prosecutor of the actual miscreants, helping fill Newgate and providing much employment for the hangman at Tyburn." (Caffentzis, 1989:19) Those who tampered with the symbols of sovereignty were sentenced to capital punishment ${ }^{24}$ and publicly executed. The severity of the punishment indicates that the offences perceived before the crisis in an almost indulgent way were no longer tolerated. The officers of the "monetary police" 25 displayed a lot of energy. In 1699, Newton became Warden of the Mint.

Under Locke's (and Newton's) authority, rules promulgated in correspondence to these ethics were respected, which consequently conserved the integrity of the coins. Through the circulation of the new coins which had the inscription "Decus and Tutamen" (Glory and Defence) on their edge, the routine dimension of public faith was restored. This reform prevented endless discussions about the quality of coins during transactions. The payment system appeared to be preserved. The expansion of English finance doubtless required such a supervision of the procedures of coinage necessary for a reliable delivery of the coins. To take Locke's expression, England's "Fiduciary Power" had beeen

22 "And so for the first time since the great recoinage of the pollards in the year 1299, a recoinage was effected which restored entirely the standard that had existed before the debasement", Feaveryear (1931: 135).

23 “During Newton's first three years at the mint, he imprisoned more than one hundred suspected clippers and counterfeiters. In his first full year, there were at least fifteen executions at Tyburn for coinage crimes in London alone [...]", Wennerlind (2004: 147). See also Craig (1963).

24 "In the case of forgery, the more exemplary punishment called for in the statute was the gallows. [...] it represented the most solemn spectacle in the armoury of justice. It addressed the entire community.", Mc Gowen (1999: 135).

25 See Linebaugh (1991: 56). 
strengthened. Having said that, the repressive policy completed the new monetary system more than founded it. Succeeding the reform, pressure aimed at supporting trust and not at decreeing it arbitrarily. In France, for example, during the assignats experiment (banknotes used during the French Revolution), the threat of the guillotine in case of refusal of notes aimed at forcing the acceptance of that instrument, but unsuccessfully.

\section{Toward a monetary revolution}

From the Middle Ages to the early modern period, minting was the first manufacturing industry to be gathered in the hands of princes. The scarcity of coins, poor technical devices, prince's manipulation and the tolerance in society paved the way for a steady degradation of the circulating medium This general context constituted the background for Bodin, Mariana and Locke's proposals. Whatever their scientific relevance, their concrete feasibility or their historical fortune, they announced what has been sometimes considered as the monetary revolution of the $18^{\text {th }}$ century.

\subsection{Counteracting falsification: convergence between the three authors}

In the context of specific countries that shared the same metallic monetary system current throughout Europe, Jean Bodin, Juan de Mariana, and John Locke, were three major thinkers who devoted an impressive number of pages to monetary troubles relating to falsification (broadly conceived). Beyond their divergences, which may be explained by distinct moral, social and political positions as well as distinct periods and countries, the three "Johns" featured several common ideas.

An important part of their analytical work was centred on sovereignty and commonwealth. But, whereas Bodin legitimated the principle of absolute sovereignty, stating that the prince himself does not have to show obedience to his laws, Mariana and Locke developed a constitutionalist view in which such a principle was clearly refused, the prince having to show, like his subjects, obedience to the laws. This induced a distinct position on the moral consequences of debasement or enhancement: this was clearly robbery for Mariana and Locke (Mariana considering it an evil, if not consented by people), while Bodin avoided such a term. However, Bodin stated that the value and the content of the currency were not a matter of law but of a contract between the sovereign and his subjects, thus setting up practical limits to the principle of absolute sovereignty in the specific field of money ${ }^{26}$. Bodin proved to be not so far from Mariana's position on monetary sovereignty, while Locke's doctrine consisted in extracting money from the

\footnotetext{
26 In this domain, his positions were close to Oresme's writings: in the Treatise of Money (1355), Oresme explained that the prince should act for the «common good» : «in order to prevent fraud... the money... should be made by a public person... And since the Prince is a more public person, and of a higher authority, it is convenient that, for the community, he should have money made.» (Oresme 1355, chapter 5), see Lapidus, 1997.
} 
royal's scope, thus leaving no latitude to the prince. Bodin and Locke considered princes manipulating the currency as falsifiers, and Bodin and Mariana recalled the story of that king Philippe IV the Fair - although Mariana avoided considering the prince's manipulation as falsification.

Beyond these differences, a common concern about the ability to debase the currency led them to strongly affirm the necessity, for economic stability as well as for public faith and, therefore, civil peace, of a metallic system able to prevent any form of false money, be they operated by individuals or princes. There is then clearly a subordination of falsification by individuals to falsification by princes and their administration; indeed, suppressing the former requires first to suppress the latter. But, whereas it was politically very easy and common to denounce counterfeiters and clippers, it could be much more risky to denounce present monarchs, their courtiers and advisers as well as high officials of the Mint. Mariana learnt this to his cost, experiencing jail, then confinement. Bodin, who once gained the King's confidence, finally lost it after having freely exposed brave positions on money and finance. Locke, on the contrary, succeeded in gaining and keeping high official position in the Glorious Revolution's new regime.

Bodin, Mariana and Locke were metallists, whose priority was the necessity of building a stable and pure metallic monetary system which was falsification proof. This leads to put secondary the quantity problem (although all three, to various degrees, went to discuss the link between prices and money quantity) and subordinate it to the problem of metallic quality of money. But whereas Locke conceived money as pure metal by essence, being a "theoretical metallist" under Schumpeter's definition (Schumpeter, 1954: 288), Bodin and Mariana were rather "practical metallists", since they viewed the implementation of a full-bodied coins system as the way to reach monetary stability, but not as the very essence of money: they saw money as primarily the creature of the sovereign.

Disregarding specific divergences, all three aimed at establishing a system of coins of pure metal (gold, silver, and, quite debated, copper), whose legal value would have to be adjusted to its intrinsic value (with debate on brassage and seigniorage). This would correspond to what Mariana called a "well-constituted republic". Related to those monetary reflections, the three authors went on to analyse the ways the royal expenses could and should be covered, since the monetary expedient would disappear. They shared a similar position too: finding moral limits to expenses, and analysing, from both an economic and moral viewpoint, advantages and disadvantages of different means to levy funds.

\subsection{Stabilization as a "monetary revolution"}

The sequence of works starting with Bodin, continuing with Mariana and ending with Locke extended over nearly 130 years. At the end of this long period, a "monetary revolution" took place. Whereas Bodin and Mariana's proposals were confined to the 
sphere of ideas (despite their own wills), Locke's arguments against debasement constituted a landmark for the English monetary history.

In their works, falsification by princes (enhancement and debasement) had to be definitively rejected, and the improvement of minting processes was a way to eliminate individual falsification. Debased and enhanced currencies were opposed to an ideal currency whose legal value depended only on the metallic content. The stabilization of the currency and the standardisation of specie were the two faces of the same coin, i.e. the setting of a stable monetary medium. This entire process articulated routine, hierarchical and ethical faith (respectively, confidence, credibility and trust). First, the royal arbitrary, allowing princes to abuse their privileges on money, had to be abolished; morals and the growing awareness of the need for economic stability contributed to this dramatic change. Thus, rejecting the secular habit of continual falsification through debasement and enhancement, sovereigns would consolidate their legitimacy. In its ethical dimension, trust in money appears clearly as a corollary of hierarchical credibility of the State administrators of the political body. As regards credibility, the control over coinage, contested by the counterfeiters, had to be re-appropriated. In the same movement, sanctions against clippers and private money-makers should strengthen the confidence through making routine uses of money more safety.

The stabilization of the currency with respect to the system of account, and the refusal of princes' debasement and enhancement, constituted major economic and political issues. Indeed, the growing use of private claims in the sphere of payments and the lengthening of credit terms required reassuring creditors as to the convertibility of their monetary and financial instruments. "With the growth of private credit, in which the rise of capitalism had its origins, mistrust of the money of account hindered the productive utilisation of savings. [...] The monetary revolution preceded the industrial revolution by a good half-century. [...] the most important factor was the institution of a system in which a (private) bank issued a currency, trust in which was maintained by convertibility into a high quality metal currency constituting a monetary base which was itself linked to the unit of account via a ratio decreed by the sovereign." (Aglietta, 2002:41-42) Thus, the rejection of further monetary depreciation in England in 1695, the French stabilization in 1726, the Spanish "stability" at the same period and other European cases ${ }^{27}$, were not mere accidents: those long term moves were required to let the credit develop. As long as a doubt subsisted on the means of payment someone received for his claim, capitalist lending processes were confined to a small part of society (involved principally in international exchanges) and estates were the best means to secure wealth. Only a solid

\footnotetext{
27 After the reform of 1726 (led by cardinal Fleury), the French king promised to avoid further debasements (see Tabatoni, 1999). E.J. Hamilton called the beginning of the $18^{\text {th }}$ century in Spain, the time of "stability". For a general overview of Europe at that time, see Tucci, 1984.
} 
degree of confidence in the money-object permitted financial developments, and eventually, industrialization ${ }^{28}$. In the same manner Luddites, who offended the means of production, were combated in order to protect capital in the $19^{\text {th }}$ century, monetary falsifiers in a broad sense, be they private or public, were rejected during the $18^{\text {th }}$ century.

\section{References}

Addison Joseph, 1710, "History of a Shilling», in Erin Mackie, ed, 1998, The Commerce of Everyday Life, Bedford, Boston, pp.183-187

Aglietta Michel, 2002, "Whence and Whither Money ? ", The Future of Money, OECD

Aglietta Michel, 2006, «Les univers des monnaies métalliques jusqu’à la première guerre mondiale », Collège international de philosophie, Paris, $22 \mathrm{p}$.

Aglietta Michel, Orléan André (eds), 1998, La monnaie souveraine, Odile Jacob, Paris

Andreau Jean, Carré Guillaume, Carrié Jean-Michel and Lamouroux Christian, 2007, "La fiduciarité des monnaies métalliques : une comparaison historique », in La monnaie dévoilée par ses crises. Volume 1 : Crises monétaires d'hier et d'aujourd'bui, Bruno Théret ed., Paris: Editions de l'EHESS, pp. 265-303.

Appleby Joyce O., 1978, Economic Thought and Ideology in Seventeenth-Century England, Princeton, Princeton University Press

Alighieri Dante, (1867) The Divine Comedy, Translated by Henry Wadsworth Longfellow, London, Routledge.

Arestis Philip, Howells Peter, 2002, « The 1520-1640 'great inflation': an early case of controversy on the nature of money », Journal of Post-Keynesian Economics, 24(2), pp. 181203.

Ashcraft Richard, 1986, Revolutionary Politics \& Locke's Two Treatises of Government, Princeton, Princeton University Press.

Beltrán Luis, 1987, "Introduction », in: Juan de Mariana, Tratado y discurso sobre la moneda de vellón (1609), Madrid, pp. 7-24.

Blanc Jérôme, 2006, « Les monnaies de la république. Un retour sur les idées monétaires de Jean Bodin », Cabiers d'économie politique, no 50, pp. 167-192.

Blanc Jérôme, 2007, « Beyond the quantity theory. A reappraisal of Jean Bodin's monetary ideas », in: Alberto Giacomin and Maria Cristina Marcuzzo (Eds.), Money and

\footnotetext{
28 "If the English state were not even able to maintain the authenticity and solidity of its own currency,
} London's status as the center of the world currency seemed infeasible.”, Wennerlind (2004: 139). 
Markets. A Doctrinal Approach, Routledge (Routledge Studies in the History of Economics), pp. 135-149.

Bodin Jean, 1568, «La response de Maistre Jean Bodin advocat en la Cour au Paradoxe de Monsieur de Malestroit, touchant l'encherissement de toutes choses, et les moyens d'y remedier ", in J.-Y. Le Branchu (ed.), 1934, Ecrits notables sur la monnaie (XVIe siècle). De Copernic à Davanzati, vol. 1, Paris: Félix Alcan.

Bodin Jean, 1578, « Discours de Jean Bodin, sur le rehaussement et diminution tant d'or que d'argent, et le moyen d'y remédier, aux paradoxes du Sieur de Malestroit », in Les six livres de la République, 1986, vol. 6, Paris: Fayard.

Bodin Jean, 1593, Les six livres de La République, Paris: Fayard, 1986.

Bouterouë, Claude, 1666, Recherches curieuses des monoyes de France depuis le commencement de la monarchie, Paris, Sebastien Cramoizy and Sebastien Mabre-Cramoisy.

Boyer-Xambeu Marie-Thérèse, Deleplace Ghislain, Gillard Lucien, 1994 (1986), Private Money and Public Currencies: The 16th Century Challenge, New York, M.E. Sharpe

Briot Nicolas, 1615, Raisons et moyens pour rendre et faire toutes les monnaies du royaume, à l'avenir, uniformes et semblables et faire cesser toutes falsifications, Paris.

Cailleux André, 1980, «L'allure hyperbolique des dévaluations monétaires », Revue de Synthèse, 99-100, pp.251-256

Caffentzis George Constantine, 1989, Clipped Coins, Abused Words and Civil Government, Locke's Philosophy of Money, Autonomedia, New-York

Caffentzis George Constantine, 2007, « Fiction or Counterfeit? Hume's philosophical politics of Money », in David Hume's Political Economy, M. Schabas and C. Wennerlind (eds), Routledge, London, pp.146-167.

Chafuen Alejandro A., 2002, "Introduction », Journal of Markets and Morality, 5, no 2, pp. 527-532.

Cotton Robert, 1626, "A Speech made before the Lords Privy Council touching the Alteration of Coin », in Mc Culloch, 1856, A Select Collection of Scarce and Valuable Tracts on Money, pp.121-141.

Craig John, 1963, "Isaac Newton and the counterfeiters", Notes and Records of the Royal Society of London, 18, 2, pp.136-145.

De Roover Raymond, 1949, Gresham on Foreign Exchange, Harvard University Press, Cambridge 
Desmedt Ludovic, 2007, «Les fondements monétaires de la Révolution financière Anglaise : le tournant de 1696 », in La monnaie dévoilée par ses crises. Volume 1 : Crises monétaires d'bier et d'aujourd'bui, Bruno Théret ed., Paris: Editions de l'EHESS, pp.311-338

Fantacci Luca, 2005, « Complementary Currencies: A Prospect on Money from a Retrospect on Premodern Practices », Financial History Review, 12, no 1, pp. 43-61.

Feavearyear A. E., 1931, The Pound Sterling. A History of English Money, Oxford University Press, London.

Feller Laurent, 1986, Faux-monnayeurs et fausses monnaies en France à la fin du Moyen Age (seconde moitie du XVe siècle), Paris: Le Léopard d'or.

Fleetwood William, 1694, A Sermon against Clipping, London

Font de Villanueva Cecilia, 2006, « Monetary reform in times of Charles II (16791686): Aspects concerning the issued dispositions », Working Papers in Economic History, Universidad Carlos III, Departamento de Historia Económica e Instituciones, Madrid, No 06-07.

Gould J.D., 1970, The Great Debasement in Mid-Tudor England, Clarendon Press, Oxford.

Hamilton Earl J., 1947, War and Prices in Spain, 1651-1800, Cambridge Mass., Harvard University Press.

Jefferies Claudia, 2010, «Monetary Theory and Monetary Policy in Castile during the first half of the $17^{\text {th }}$ Century ", to be published in : J. Blanc and L. Desmedt (eds), Les pensées monétaires dans l'bistoire, 1517-1776, forthcoming.

Kelly Patrick Hyde, 1991, "General introduction», in Locke on Money, vol. I, Oxford, Clarendon Press

Kleer, Richard A., 2004, "'The ruine of their Diana': Lowndes, Locke, and the Bankers », History of Political Economy, 36: 3, pp.533-556.

Lapidus André, 1997, "Metal, Money, and the Prince : John Buridan and Nicholas Oresme after Thomas Aquinas", History of Political Economy, 29: 1, pp.21-53

Laslett Peter, 1970, "Two Treatises of Government and the Revolution of 1688", in Locke 1689-1970, pp.45-66.

Lewis David K., 1969 (1986), Convention. A philosophical study, Basil Blackwell, Londres

Linebaugh Peter, 1991, The London Hanged. Crime and civil society in the eighteenth century, Penguin, London 
Locke John 1689, Two Treatises of Government, ed. by P. Laslett, Cambridge University Press, 1970.

Locke John 1691, $2^{\text {d }}$ ed. 1696, Some Considerations of the Consequences of the Lowering of Interest, and Raising the Value of Money in Locke on Money, 1991, vol. I, Oxford, Clarendon Press

Locke John, 1695, Further Considerations concerning Raising the V alue of Money, in Locke on Money, Clarendon Press, Oxford, 1991, vol.II, pp.399-481

Lowndes William, 1695, A Report Containing an Essay for the Amendment of the Silver Coins, London

Mc Culloch John Ramsay, 1856, A Select Collection of Scarce and Valuable Tracts on Money, The London Political Economy Club, London

Mc Gowen R., 1999, «From pillory to gallows : the punishment of forgery in the age of the financial revolution », Past and Present, 165, pp.107-140

Macaulay Thomas Babington, 1861 (1948), History of England from the Accession of James II, vol. 3, Dent and sons, London

Macleod Henry Dunning, 1896, The History of Economics, Bliss, Sands \& Co, London

Malestroit Jehan Cherryut de, 1934 [1566], "Les paradoxes du seigneur de Malestroict, Conseiller du Roi et maistre ordinaire de ses comptes, sur le faict des monnoyes présentez a sa majesté, au mois de mars, MDLXVI", in J.-Y. Le Branchu ed., Ecrits notables sur la monnaie (XVTe siècle). De Copernic a Davanzati, vol. I, Félix Alcan, Paris

Mariana Juan de, 1609, "De monetae mutatione », in Tractatus Septem, Coloniae Agrippinae, pp. 199-231.

Mariana Juan de, 2002, "A treatise on the alteration of money », Journal of Markets and Morality, 5, no 2, pp. 523-593. (English translation from P. T. Brannan)

Ménard Olivier 2004, "De la répression de la fausse monnaie en Bretagne au XVIIIe siècle », Revue Numismatique, 2004, pp.321-342.

Montchrétien Antoyne de, 1889 [1615], L'économie politique patronale. Traicté de l'oeconomie politique dédié en 1615 au Roy et à la Reyne mère du Roy, Plon, Paris

Muldrew Craig, 2001, «'Hard Food For Midas': Cash and its social value in Early Modern England », Past and Present, 170, pp.78-120

Newton Isaac, 1724, "Report of Newton's assay of Wood's coinage », in The Drapier's letters, Blackwell, London, pp.187-188.

Nussbaum Arthur, 1950, Money in the law, national and international. A comparative study in the borderline of law and economics, Brooklyn: Foundation Press 
O'Brien Dennis P., 2000, "Bodin's Analysis of Inflation», History of Political Economy, 32(2), pp. 267-92.

Ögren Anders and Runefelt Leif, 2010, « Monetary Theory and Practice in Sweden, 1521 - 1776 », to be published in: J. Blanc and L. Desmedt (eds), Les pensées monétaires dans l'bistoire, 1517-1776, forthcoming.

Oresme Nicolas, 1355 (1989), "Traité des monnaies", in C. Dupuy (éd.), Traité des monnaies et autres écrits monétaires du XIVe siècle, Lyon, La Manufacture

Pamuk Sevket, 2000, A Monetary History of the Ottoman Empire, Cambridge U.K., Cambridge University Press

Parsons Jotham, 2003a, « Governing Sixteenth-Century France: The monetary Reforms of $1577 »$, French Historical Studies, 26, pp. 1-30.

Parsons Jotham, 2003b, "Coinage, Counterfeit and Satire », N.E.H. Summer Seminar, "Surveying Paris: Urban Space and Urban Culture in the Early Modern City", 22 July 2003.

Pepys Samuel, 1660-1669, The Diary, ed by R. Latham, W. Matthews, G. Bell and Sons, London, 11 vol.

Raskov Danila, 2007, "Economic thought of Muscovy: Ownership, Money and Trade », $11^{\text {th }}$ ESHET Conference, "Justice in Economic Thought", Strasbourg, July 5- th $^{\text {th }}$

Ruding Rogers, 1819, 1840, Annals of the Coinage of Britain and its dependencies, London

Sargent Thomas and Velde François, 2003, The Big Problem of Small Change, Princeton: Princeton University Press

Schnabel Isabel \& Shin Hyun Song, 2006, « The 'Kipper und Wipperzeit' and the Foundation of Public Deposit Banks», Second Economic History Panel, Bank of England, november 23-24

Schumpeter, Joseph A., 1954, History of Economic Analysis, London: Allen and Unwin.

Tabatoni Pierre, 1999, Mémoire des monnaies européennes du denier à l'euro, P.U.F., Paris

Théret Bruno, 2007, "The three states of money, or money as a cultural capital », Workshop "Visit Monetary History of A Quarter of Human Beings and Revisit What Monies Actually Are", Tokyo University, Tokyo, 21-22 mai 2007.

Théret Bruno (ed.), 2007, La monnaie dévoilée par ses crises, Editions de l'EHESS, Paris

Tucci Ugo, 1984, «Le rapport or/argent dans l'économie monétaire européenne du XVIIIe siècle », in Etudes d'Histoire Monétaire XIIe-XIXe siècles, John Day ed, P.U.L., Lille 
Turquam Thomas, 1573, Remonstrances faites au parlement de Dijon le X. jour de septembre 1573, par M. Thomas Turquam,... commissaire député par sa Majesté pour l'exécution du descry des espèces de billon estrangères qui s'exposent au duché de Bourgongne, J. Dallier, Paris

Valenze Deborah, 2006, The social life of money in the English past, Cambridge University Press, New York

Wennerlind Carl, 2004, "The Death Penalty as Monetary Policy: The Practice and Punishment of Monetary Crime, 1690-1830», History of Political Economy, 36 :1, pp.131-161. 